Received February 21, 2018

Revised June 13, 2018

Accepted June 18, 2018

\title{
Corporate Governance Structure and Accounting Information Disclosure Quality: Evidence from Shenzhen Stock Exchange in China*
}

\author{
HE XU ${ }^{* *} \cdot$ CHANG SEOP RHEE ${ }^{* * *}$
}

This study investigates the effect of corporate governance structure on the quality of accounting information disclosure using Shenzhen stock exchange data. Existing literatures reported that corporate governance can help to improve accounting quality. However, China's corporate governance structure may have different consequences from prior studies because it has less maturity than developed countries in Europe and the United States. China government, in particular, has a very strong influence on the companies in China and we needs to be verified if the corporate governance structure works properly.

From the empirical tests, we find that the proportion of stateowned shares, the proportion of tradable shares, ownership concentration, the size of the board of directors, the proportion of ownership of the board of directors, and size of the board of supervisors are positively associated with the quality of accounting information disclosure. This study will contribute to academics and practitioners by documenting the factors of corporate governance structure on accounting disclosure quality in China.

Keywords: Corporate Governance, Accounting Information

Disclosure, Ownership Structure, Board of Directors,

Board of Supervisors, Chinese Capital Market.

* This paper is based on Master's thesis of the first author, $\mathrm{He} \mathrm{Xu,} \mathrm{at} \mathrm{Sejong}$ University.

** First Author, Master's student, School of Business, Sejong University, Korea; E-mail: xuhe-bestwish@foxmail.com

*** Corresponding Author, Assistant Professor, School of Business, Sejong University, Korea; E-mail: crhee2@sejong.ac.kr

DOI: 10.16934/isr.19.1.201806.99 


\section{INTRODUCTION}

Since the last century, many accounting fraud scandals have occurred in different countries (e.g. Enron and WorldCom scandals in the U.S., the Bank of Credit and Commerce International, and the Maxwell Communication in the U.K., and the Daewoo in Korea). The accounting fraud scandals are mostly committed by managers, and they manipulate firms' earnings to seek their own interests rather than shareholders' under the weak corporate governance structure. To prevent the accounting scandals, the U.S. government passed the Sarbanes-Oxley Act in 2002 and strictly regulates the capital market (Romano 2004; Zhang 2007). In particular, the need for a stronger corporate governance structure was emphasized as a way to improve the quality of accounting information disclosure.

Existing literatures generally reported that corporate governance can help to improve accounting quality. However, China's corporate governance structure may have different consequences from prior studies because it has less maturity than developed countries in Europe and the United States. In particular, unlike the United States and Europe, the Chinese government has a very strong influence on its companies, and it is an interesting research question whether corporate governance works properly under strong influence of government.

To verify this, we perform empirical tests to examine the association between the corporate governance structure of Chinese firms and the quality of accounting information disclosure. Specifically, we classify the corporate governance structure largely into three types: ownership structure, characteristics of board of directors, and characteristics of board of supervisors, and then conduct a logistic regression analysis using Chinese listed firm data. From the empirical results, we find that the proportion of state-owned shares, the proportion of tradable shares, ownership concentration, the size of the board of directors, the proportion of ownership of the board of directors and size of the board of supervisors are positively associated with the quality of accounting information disclosure. We expect that this paper contributes to academics and practitioners by reporting various corporate governance which affects accounting disclosure quality in China.

The rest of this paper is organized as follow; Section2 discusses the prior researches and develops our reasoning, and Section 3 provides the research methodology. Section 4 reports the empirical results, and Section 5 concludes the paper. 


\section{BACKGROUND AND HYPOTHESIS DEVELOPMENT}

\section{Corporate Governance in China}

The discussion of corporate governance included the agency problem of separation of ownership and management rights (Jensen \& Meckling, 1976). This mechanism requires mutual checks and balances between the owners and the managers to control the firms. Due to the difference between social systems and the level of economic development, corporate governance structures vary from country to country. In the U.S., the corporate governance structure of a company is usually made up of shareholders meeting, board of directors and chief executive officers. Although the shareholder meeting is the supreme authority, its functions are usually carried out by the board of directors. The shareholders meeting elects some of the major shareholders or some of the authoritative shareholders to form a board of directors, and then the shareholders delegate the day-to-day decision-making power of company to the board of directors. In this way, the principal-agent relationship is built .The corporate governance structure of the U.S. is called the unitary board system which is characterized by the fact that the board is both a business executive agency and a supervisory authority.

Chinese listed companies are required to set up a board of directors and a board of supervisors, and it is defined in Chinese company law. This type of corporate governance structure is called the bicameral board system. The board of directors and the board of supervisors are accountable to the shareholders meeting and accept its leadership. In China, the board of supervisors is established in parallel with the board of directors, and accepts the leadership of the shareholders meeting. It is noteworthy that there is no affiliation between the two boards. The board of directors is the executive body of the company which can execute the decision of the shareholders meeting and participate in day-to-day decisions of the company. The board of supervisors is the oversight body of the company which can supervise the legality of the finance of company and inspect the operating behavior of the board of directors, general manager, chief financial officer and others. In this way, the board of supervisors can safeguard the legitimate rights and shareholders' interest. Figure 1 provides a diagram of corporate governance structure of Chinese listed firms. 


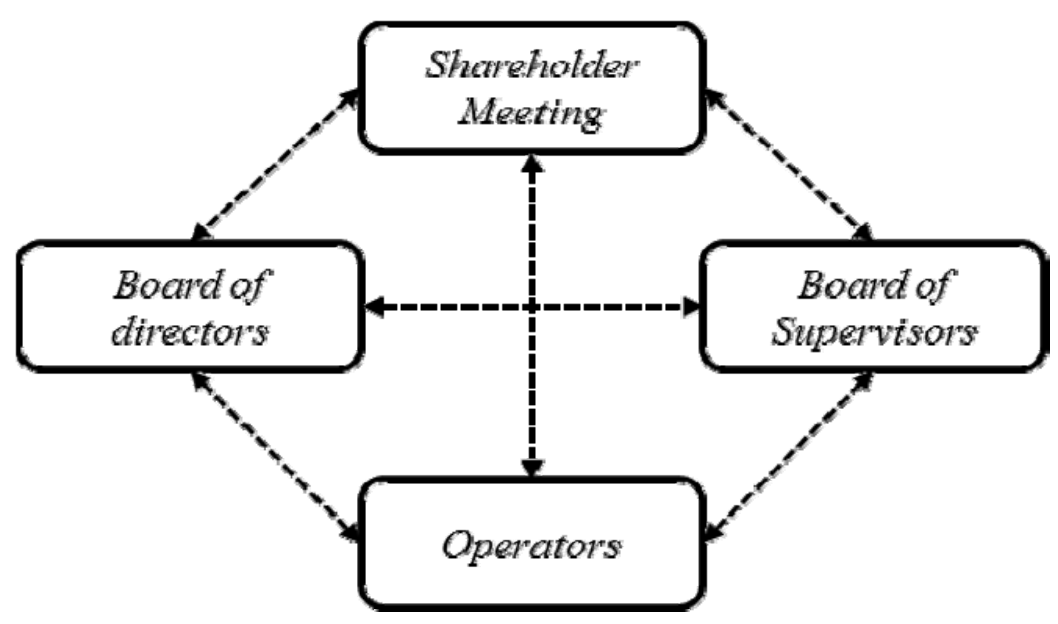

FiguRE 1. DIAGRAM OF CHINESE CORPORATE GOVERANCE STRUCTURE

\section{Accounting Information Disclosure Quality}

We consider that there is relevance between the corporate governance structure and the quality of accounting information disclosure. Strong corporate governance structure is conducive to improving the quality of accounting information disclosure. Under the strong corporate governance structure, it is difficult for the managers to manipulate the earnings for their own interests. Ultimately, firms' the level of quality of accounting information disclosure would be improved from the strong corporate governance structure.

The characteristics of Chinese corporate governance structure and its impact on the quality of accounting information are as follows. First, in the Chinese securities market, the proportion of state-owned shares is high, and the equity is more concentrated. Because of the state-owned economy holds the lifeblood of the national economy, most of the listed companies in China are controlled by the state. And the managers of these listed companies are mostly government officials. Some of them, in order to get a promotion, provide false accounting information. It may harm the interests of small shareholders.

Second, the board of directors of the listed companies is actually controlled by the operator. The board of directors lacks independence and becomes an empty shelf without reasonable decision-making. Independent directors in the board of directors are also controlled by other members, and making it difficult to act independently. Moreover, the board of directors is often staffed by the internal staff of the listed companies. Therefore, it cannot play the role of supervising and controlling the operators. Thus, it can be said that such a corporate governance structure is likely to cause distortion of accounting information disclosure. 


\section{Prior Study about Corporate Governance Structure and Earnings Quality}

Most study about corporate governance structure and earnings quality investigate the association the proxy of corporate governance structure and the level of discretionary accrual. Courteau et al. (2001) show that the higher the proportion of external directors, the less the manipulation of earnings. They also find that the size of board of the directors reduce the management' earnings management behavior. Chau and Gray (2002) use the Hong Kong and Singapore listed companies as a sample to study ownership structure and the relationship between the levels of voluntary disclosure. They find that there is a positive association between the proportion of outsider holdings and voluntary disclosure. Jung and Kwon (2002) report that the large shareholder is positively related to earnings quality using Korean firm observations.

However, the Chinese study regarding the association between corporate governance structure and earnings quality provides mixed results. Cai and Liang (2003) observe the Chinese capital market, and report that there is no significant relationship between independent directors and accounting frauds. But the ownership concentration is negatively associated with the earnings quality. Liang (2004) performs an empirical analysis of 35 listed companies that were punished by China Securities Regulatory Commission in 2003. The study reports that there is a no significant association between board characteristics and accounting frauds. Zhang et al. (2006) shows that the size of the board of supervisors leads to the decline in the degree of earnings management, and the board of supervisors prevent earnings management. Du and Wen (2007) finds that the higher the proportion of independent directors in listed companies, the higher the quality of accounting information.

In this study, we use the quality of accounting information disclosure reported by the Shenzhen Stock Exchange as a proxy of earnings quality. Also, we introduce more specific proxies of corporate governance structure and then examine the influence of corporate governance on the quality of accounting information disclosure.

\section{Hypothesis Development}

\section{1) Proportion of state-owned shares}

Generally, state-owned shares include state shares and state-owned legal person shares. State-owned shares represent the interests of the state. From the ownership structure, state-owned shares are not in circulation in the capital market. State-owned shareholders not only pay attention to economic benefits, but also pay attention to social benefits. Especially, in China, a public ownership 
as the main body of the socialist countries, the willpower of the government will have a significant impact on the company business decisions. The abuse of the power could possibly lead to poor quality of accounting information. In summary, this paper presents the following hypothesis.

H1: The proportion of state-owned shares is negatively associated with the quality of accounting information disclosure.

\section{2) Proportion of tradable shares}

Generally, it is considered that the growth level of the stock market is high as the proportion of tradable shares increases. The shareholders of the tradable shares can take certain control and make a significant influence on their company through the shareholders meeting. In this circumstance, manager may have pressure to manipulate accounting information because of the monitoring effect from a large number of shareholders. Therefore, the manager will be committed to the company business and improve company performance. In summary, this paper presents the following hypothesis.

H2: The proportion of tradable shares is positively associated with the quality of accounting information disclosure.

\section{3) Ownership concentration}

Shleifer and Vishney (1986) argue that a certain degree of ownership concentration is necessary, and the existence of large shareholders to solve the problem of free-ride for some of the small shareholders. The potential takeover threats imposed by large shareholders plays an important role as an effective supervisory mechanism. Large shareholders can effectively supervise the behavior of managers, and help to enhance the effectiveness of the operation of the market, and eventually reduce the agency cost (Shleifer and Vishney 1997; Warfield, Wild, and Wild, 1995). Then, equity concentration can enable large shareholders to have sufficient incentives to collect information and effectively supervise management, thus avoiding the problem of free-ride caused by highly decentralized equity. This kind of supervision involves supervising the process of generating financial reporting by management; therefore it is possible to raise the quality of financial reporting. In summary, this paper presents the following hypothesis.

H3: Ownership concentration is positively associated with the quality of accounting information disclosure. 


\section{4) Size of board of directors}

In recent years, many scholars have conducted researches about the relationship between size of board of directors and the quality of accounting information disclosure. Klapper et al. (2009) shows that companies report more accurate accounting information when the number of board member increases. At the same time, the board of directors plays a role of monitor to control management. To a certain extent, the director board will increase the efficiency of supervision, and the company accounting information will have a certain impact on the quality. As the number of the board of director increases, the number of professional gathered on the board will increases. They can analyze the problem from multiple perspectives, avoid risks effectively, and improve the quality of accounting information. In summary, this paper presents the following hypothesis.

\section{H4: The size of board of directors is positively associated with the quality} of accounting information disclosure.

\section{5) Proportion of independent directors}

In 2001, the China Securities Regulatory Commission issued its guidelines on the establishment of an independent director system in listed companies for regulating internal corporate governance through the institution of the independent director (Clarke 2006, Lau and Jin 2013). Chen and Xia (2003) report that independent directors are directly relate to the effectiveness of accounting information quality and the efficiency of external institutional arrangements. Recently, the independent director system has been paid more attention in China, and the independent director system in China gradually is improving and developing. In summary, this paper presents the following hypothesis.

H5: The proportion of independent directors is positively associated with the quality of accounting information disclosure.

\section{6) Concurrent position of chairman and general manager}

In the case of chairman and general manager of concurrent position of chairman and general manager, managers have greater decision-making power in the company's business decisions. It will inevitably result in the loss of the independence of board oversight, leading managers to manipulate earnings and harm the interests of shareholders. Especially in China, securities mechanisms, laws and regulations are not sound enough. The external oversight mechanism of the company cannot fully play a role, and is more likely to cause the problems in 
listed companies by one person's arbitrary decision. In summary, this paper presents the following hypothesis.

H6: The concurrent position of chairman and general manager is negatively associated with the quality of accounting information disclosure.

\section{7) Number of meetings of board of directors}

The board of directors exercises the supervisory function through the meeting of board directors. In China, regardless of whether there is a crisis of listed companies, the board of directors should be deliberated by the board of directors meeting. From the outside of the listed company, the more frequent board meeting, the more diligent the board members are to a certain extent. At the same time, during the meeting of board of directors, the number of the board of directors has ample time to analyze the operating conditions and financial information at the meeting of board of directors. This can greatly improve the efficiency of supervision, so as to monitor the behavior of the manager to prevent the earnings manipulation for managers. It is helpful to correct the problems in accounting information disclosure and improve the quality of accounting information disclosure. In summary, this paper presents the following hypothesis.

H7: The number of meetings of board of directors is positively associated with the quality of accounting information disclosure.

\section{8) Proportion of ownership of the board of directors}

The board of directors is an institution which is elected by the shareholders meeting and exercised management duties on its behalf. Therefore, there is a principal-agent relationship between the board of directors and the shareholders. In order to reduce agency costs, shareholders encourage the board members, and provide an incentive mechanism. If the members of the board of directors have the shares of the company, their interests with the shareholders tend to be consistent. The cost of agency will be reduced, and eventually the quality of accounting information disclosure will be improved. Bleasley (1996) shows that increased number of board members will reduce the likelihood of fraud in financial reporting. In summary, this paper presents the following hypothesis.

H8: The proportion of ownership of the board of directors is positively associated with the quality of accounting information disclosure. 


\section{9) Size of board of supervisors}

According to the provisions of the Company Law of the People's Republic of China, a limited liability company should set up a board of supervisors (Art and $\mathrm{Gu}$ 1995). A stock company with a small number of shareholders or a small limited liability company may have one or two supervisors, and do not need to set up the board of supervisors. The board of supervisors is established in parallel with the board of directors from the leadership of the shareholders meeting. In order to protect shareholders' interest, it is necessary to form a special supervisory organization at the shareholders meeting to exercise the monitoring function. In addition, the directors and senior management cannot concurrently serve as supervisors in China. This guarantees independence of the board of supervisors.

As the board of supervisors and the board of directors are set in parallel, the board of supervisors is not subject to the leadership of the board of directors, and the board of supervisors can provide better monitoring of the performance of the duties of the board of directors and the management. In summary, this paper presents the following hypothesis.

H9: The size of board of supervisors is positively associated with the quality of accounting information disclosure.

\section{0) Proportion of ownership of the board of supervisors}

Some Chinese listed companies give the board of supervisors a certain percentage of the shares as an incentive mechanism. Under normal circumstances, if the members of the board of supervisors hold the shares of the company, the members of the board of supervisors will enhance the sense of belonging to the company. The long-term development of company and the personal interests of the members of the board of supervisors linked together which is conducive to the exercise of supervisory rights by the members of the board of supervisors.

It is beneficial to the company manager to provide relevant and reliable accounting information and improve the quality of accounting information disclosure. Alchian and Demsets (1972) show that when the company granted a certain percentage of the shares to the board of supervisors, the efficiency of the board of supervisors will be improved and the quality of accounting information will be improved significantly. In summary, this paper presents the following hypothesis.

H10: The proportion of ownership of the board of supervisors is positively associated with the quality of accounting information disclosure. 


\section{RESEARCH METHODOLOGY}

\section{Variable Explanation}

In this study, we use the information disclosure evaluation results of Chinese listed companies reported by the Shenzhen Stock Exchange as a dependent variable. The Information disclosure evaluation of Chinese listed companies is assessed by dividing the results into four levels: A, B, C and D. Among these four levels, A is excellent, B is good, C is passed, and D is failed. We divide $\mathrm{A}$ and $\mathrm{B}$ into a group with a high level of information disclosure quality and $\mathrm{C}$ and $\mathrm{D}$ into a group with a low level of information disclosure quality for setting an indicator variable of Quality. Using the indicator variable of Quality, we perform the logistic regression analysis.

The independent variables in this study are derived from three types: ownership structure, characteristics of board of directors, and characteristics of board of supervisors. In this study, the proportion of state-owned shares, the proportion of outstanding shares and ownership concentration will be treated as ownership structure. Characteristics of board of directors is divided into size of board of directors, proportion of independent directors, concurrent position of chairman and general manager, the number of meetings of board of directors, and proportion of ownership of the board of directors. Characteristics of board of supervisors are divided into size of board of supervisors and proportion of ownership of the board of supervisors. We summarize the explanation of the variables in Table 1.

\section{TABLE 1. VARIABLES EXPLANATION}

\begin{tabular}{|c|c|c|}
\hline Type & Variables & Explanation \\
\hline $\begin{array}{l}\text { Dependent } \\
\text { Variable }\end{array}$ & Quality & $\begin{array}{l}\text { An indicator variable that equals to } 1 \text { if a firm's information disclosure } \\
\text { quality is high, } 0 \text { otherwise. }\end{array}$ \\
\hline \multirow{3}{*}{$\begin{array}{l}\text { Ownership } \\
\text { Structure }\end{array}$} & State & $\begin{array}{l}\text { Proportion of state-owned shares(Number of state-owned shares/Total } \\
\text { number of shares) }\end{array}$ \\
\hline & Trade & $\begin{array}{l}\text { Proportion of tradable shares(Number of tradable shares/Total number of } \\
\text { shares) }\end{array}$ \\
\hline & Owner & $\begin{array}{l}\text { Ownership concentration(Square sums of the proportion of the top five } \\
\text { shareholders) }\end{array}$ \\
\hline \multirow{5}{*}{$\begin{array}{c}\text { Characteristi } \\
\text { cs } \\
\text { of } B O D\end{array}$} & Dir & Size of board of directors(Number of board of directors) \\
\hline & Ind & $\begin{array}{l}\text { Proportion of independent directors(Number of independent directors/ } \\
\text { Number of directors) }\end{array}$ \\
\hline & Chair & $\begin{array}{l}\text { An indicator variable that equals to } 1 \text { if there is concurrent position of } \\
\text { chairman and general manager in a firm, } 0 \text { otherwise. }\end{array}$ \\
\hline & DirM & $\begin{array}{l}\text { Number of meetings of board of directors(Number of meetings of board of } \\
\text { directors) }\end{array}$ \\
\hline & ProDir & $\begin{array}{l}\text { Proportion of ownership of the board of directors(Number of shares held by } \\
\text { the board of directors/ Total number of shares) }\end{array}$ \\
\hline
\end{tabular}




\begin{tabular}{ccl}
\hline Type & Variables & \multicolumn{1}{c}{ Explanation } \\
\hline \multirow{2}{*}{\begin{tabular}{c} 
Characteristi $\begin{array}{c}c s \\
\text { of BOS }\end{array}$ \\
\cline { 2 - 3 } BOP
\end{tabular}} & SroSup & $\begin{array}{c}\text { Proportion of ownership of the board of supervisors(Number of board of Supervisors) } \\
\text { held by the board of supervisors/ Total number of shares) }\end{array}$ \\
\hline
\end{tabular}

\section{Model Specification}

In this study, the dependent variable of Quality is consistent with the binomial distribution. However, multivariate linear regression model requires that the dependent variable is continuous random variables with normal distribution. Therefore, we establish the following binary logistic regression model to examine the effect of corporate governance on accounting information disclosure quality. In the model, $i$ is used to represent company $i . \beta_{n}$ is used to represent the influence coefficient of each independent variable on the dependent variable.

$$
\begin{aligned}
& \text { Regression Model: } \\
& \text { Quality }_{\mathrm{i}}=\beta_{0}+\beta_{1} \text { State }_{\mathrm{i}}+\beta_{2} \text { Trade }_{\mathrm{i}}+\beta_{3} \text { Owner }_{\mathrm{i}}+\beta_{4} \text { Dir }_{\mathrm{i}}+\beta_{5} \text { Ind }_{\mathrm{i}}+ \\
& \beta_{6} \text { Chair }_{\mathrm{i}}+\beta_{7} \text { DirM }_{\mathrm{i}}+\beta_{8} \text { ProDir }_{\mathrm{i}}+\beta_{9} \text { Sup }_{\mathrm{i}}+\beta_{10} \text { ProSup }_{\mathrm{i}}+\varepsilon
\end{aligned}
$$

\section{Sample Selection}

The samples of this paper are based on the listed companies on the main board of the Shenzhen Stock Exchange from 2011 to 2015. The Information Disclosure Evaluation Result which was published by Shenzhen Stock Exchange in China as measure indicators of accounting information disclosure quality. The data of the independent variables were obtained from the CSMAR database system developed by Shenzhen GuoTaiAn Education \& Technology co., LTD.

We exclude listed companies with missing data. The listed companies with special treatment by China Securities Regulatory Commission were also excluded from the scope of this study, because of the emergence of a special situation in financial terms. Finally, we select a total of 2,068 listed companies as a sample to examine the effect of corporate governance structure on accounting information disclosure quality.

\section{EMPRICIAL RESULTS}

\section{Descriptive Statistics}

Table 2 provides descriptive statistics about variables of accounting information disclosure and corporate governance structure. The minimum of proportion of state-owned shares is 0.000 and the maximum is 0.841 . Some 
companies do not have state-owned shares, and some listed companies have a higher proportion of state-owned shares. The reason of the disparity is that there are many state-owned holding companies in China. The minimum of proportion of tradable shares is 0.058 and the maximum is 1.000 . It indicates that all listed companies in the sample have tradable shares. The mean value of ownership concentration is 0.155 indicating that the shares of Chinese listed companies are more concentrated. The standard deviation of the number of board of directors is 1.993. The minimum of the number of board of directors is 4.000. It does not comply with the provisions of the Company Law of the People's Republic of China on the number of members of the board of directors from 5.000 to 19.000 in joint-stock companies. This may be due to some special causes, but most of the listed companies meet this condition. The Chinese government needs to strengthen the management of this area. According to the provisions of the China Securities Regulatory Commission, the number of independent directors of listed companies should account for one-third of the total number of board members. The table above shows that the minimum of proportion of independent directors is 0.182 and the mean value is 0.372 . As can be seen from the mean value, listed companies have just reached this standard. However, individual listed companies did not meet this standard. It shows that China should improve the independent director system. Some of Chinese listed companies are formed by the reform of state-owned companies, part of the private enterprises are family business and controlled by the founder This is easy to cause the situation of concurrent position of chairman and general manager. The Chinese company law stipulates that the board meeting shall be held at least twice a year. According to the data in the table we can see, the number of meetings of the board of directors is 9.980, and the minimum value is 0.000 . Although the overall view to achieve this standard, but there are still individual companies which do not meet the standards. The minimum proportion of ownership of the board of directors is 0.000 and the maximum value is 0.427 . This shows that some companies have taken equity incentive measures. As each company view of equity incentive is different, it results in a maximum value of the smallest difference between the larger. The minimum of size of board of supervisors is 2.000 and the maximum is 14.000. This shows that the number of supervisors between the various listed companies is quite different. The minimum proportion of ownership of the board of supervisors is 0.000 and the maximum is 0.105 . This shows that some listed companies have taken incentives for supervisors. From the maximum and mean, it can be seen that the equity incentive for supervisors and the equity incentive to the directors are quite different. 
TABLE 2. DESCRIPTIVE STATISTICS

\begin{tabular}{lcccc}
\hline \multicolumn{1}{c}{ Variables } & Minimum & Maximum & Mean & Std. Deviation \\
\hline Quality & .000 & 1.000 & .830 & .374 \\
\hline State & .000 & .841 & .066 & .156 \\
\hline Trade & .058 & 1.000 & .853 & .224 \\
\hline Owner & .003 & .810 & .155 & .131 \\
\hline Dir & 4.000 & 18.000 & 8.990 & 1.993 \\
\hline Ind & .182 & .714 & .372 & .057 \\
\hline Chair & .000 & 1.000 & .180 & .381 \\
\hline DirM & .000 & 31.000 & 9.980 & 4.050 \\
\hline ProDir & .000 & .427 & .005 & .031 \\
\hline Sup & 2.000 & 14.000 & 3.911 & 1.221 \\
\hline ProSup & .000 & .105 & .000 & .002 \\
\hline
\end{tabular}

\section{Univariate Analysis}

After descriptive statistical analysis, the dependent variable and the independent variables were tested for univariate analysis. Through the univariate analysis, the relationship between the variables can be shown clearly. Thus, a correlation test can determine whether there are significant relationship between variables and whether it meets the needs of the next step. The correlations between variables are shown in table 3 .

TABLE 3. CORRELATIONS BETWEEN VARIABLES

\begin{tabular}{|c|c|c|c|c|c|c|c|c|c|}
\hline Variables & Trade & Owner & Dir & Ind & Chair & DirM & ProDir & Sup & ProSup \\
\hline \multirow{2}{*}{ State } & $-.636^{* *}$ & $.275^{* *}$ & $.080^{* *}$ & -.027 & $-.069 * *$ & $-.050^{*}$ & $-.048^{*}$ & $.134 * *$ & -.015 \\
\hline & $(.000)$ & $(.000)$ & $(.000)$ & $(.224)$ & $(.002)$ & $(.022)$ & $(.030)$ & $(.000)$ & $(.485)$ \\
\hline \multirow{2}{*}{ Trade } & & $-.325 * *$. & -.024 & .005 & -.004 & $-.066^{*}$ & $-.179 * *$ & -.020 & $-.043^{*}$ \\
\hline & & $(.000)$ & $(.285)$ & $(.820)$ & $(.851)$ & $(.002)$ & $(.000)$ & $(.362)$ & $(.048)$ \\
\hline \multirow{2}{*}{ Owner } & & & .032 & .024 & $-.121 * *$ & .040 & $-.056^{*}$ & $.070 * *$ & -.020 \\
\hline & & & .145 & .265 & .000 & .070 & .011 & .001 & .356 \\
\hline \multirow{2}{*}{ Dir } & & & & $-.383 * *$ & $-.109^{* *}$ & $.044^{*}$ & .001 & $.273^{* *}$ & .024 \\
\hline & & & & .000 & .000 & .048 & .948 & .000 & .276 \\
\hline \multirow{2}{*}{ Ind } & & & & & $.093 * *$ & $.047^{*}$ & .033 & $-.104 * *$ & .010 \\
\hline & & & & & .000 & .032 & .139 & .000 & .643 \\
\hline \multirow{2}{*}{ Chair } & & & & & & -.029 & $.164 * *$ & $-.101 * *$ & .016 \\
\hline & & & & & & .194 & .000 & .000 & .464 \\
\hline \multirow{2}{*}{ DirM } & & & & & & & .002 & .022 & $.046^{*}$ \\
\hline & & & & & & & .915 & .310 & .038 \\
\hline \multirow{2}{*}{ ProDir } & & & & & & & & $-.066^{* *}$ & $.112^{* *}$ \\
\hline & & & & & & & & .003 & .000 \\
\hline \multirow{2}{*}{ Sup } & & & & & & & & & -.025 \\
\hline & & & & & & & & & .250 \\
\hline
\end{tabular}

Note: $* * *$ indicate, respectively, the significance level at the $1 \%$ and $5 \%$ level (2-tailed). 


\section{Logistic Regression Analysis}

Table 4 provides the empirical result of the logistic regression model. The beta coefficient of the proportion of state-owned shares (State) is 1.380, and the significant value is 0.011 . This means the proportion of state-owned shares is positively associated with the accounting information disclosure quality; the result is opposite to hypothesis 1 . In China, companies with a high proportion of state-owned shares can fulfill their responsibilities to stakeholders and provide high-quality accounting information. The beta coefficient of the proportion of tradable shares (Trade) is 1.544 , and significant value is 0.000 . This shows that the proportion of outstanding shares is positively associated with the accounting information disclosure quality; the result supports hypothesis 2. The beta coefficient of ownership concentration (Owner) is 2.729, and significant value is 0.000 . This means that ownership concentration is positively associated with the accounting information disclosure quality; the result supports hypothesis 3 .

The beta coefficient of size of board of directors (Dir) is 0.123 , and significant value is 0.001 . This shows that size of board of directors is positively associated with the accounting information disclosure quality, the result supports hypothesis 4 . This indicates that bigger size of the board of directors can improve firms' accounting information disclosure quality in China. The beta coefficient of the proportion of independent directors (Ind) is -0.160 , and significant value is 0.887 . This indicates that the proportion of independent directors is negatively associated with the quality of accounting information disclosure, but it is not significant. It may be that the independent directors of Chinese listed companies are recommended by the major shareholders in the general meeting. Therefore, the independent directors are not perfectly independent from the control of the major shareholders and not able to make a significant influence to firms' accounting information disclosure quality. For the reason, the Chinese government should improve the system of independent directors to improve the quality of accounting information disclosure. The beta coefficient of concurrent position of chairman and general manager (Chair) is -0.225 , and significant value is 0.132 . It shows that the concurrent position of chairman and general manager is negatively associated with the quality of accounting information disclosure, but it is not significant. The beta coefficient of number of meetings of board of directors $(\operatorname{DirM})$ is 0.014 , and significant value is 0.365 . This shows that the number of meetings of board of directors is positively associated with the quality of accounting information disclosure, but it is not significant. The beta coefficient of the proportion of ownership of the board of directors (ProDir) is 6.190, and significant value is 0.023 . It indicates that the proportion of ownership of the board of directors is positively associated with the accounting information disclosure quality; the result supports hypothesis 8 . 
The beta coefficient of the size of board of supervisors (Sup) is 0.158 , and significant value is 0.007 . It shows that the size of board of supervisors is positively associated with the accounting information disclosure quality; the result supports hypothesis 9 . The beta coefficient of the proportion of ownership of the board of supervisors (ProSup) is 0.666 , and significant value is 0.981 . It means that the proportion of ownership of the board of supervisors is positively associated with the quality of accounting information disclosure, but it is not significant.

TABLE 4. LOGISTIC REGRESSION ANALYSIS

$$
\begin{aligned}
\text { Quality }_{\mathrm{i}}= & \beta_{0}+\beta_{1} \text { State }_{\mathrm{i}}+\beta_{2} \text { Trade }_{\mathrm{i}}+\beta_{3} \text { Owner }_{\mathrm{i}}+\beta_{4} \text { Dir }_{\mathrm{i}}+\beta_{5} \text { Ind }_{\mathrm{i}}+ \\
& \beta_{6} \text { Chairi }+\beta_{7} \text { DirM }_{\mathrm{i}}+\beta_{8} \text { ProDir }_{\mathrm{i}}+\beta_{9} \text { Sup }_{\mathrm{i}}+\beta_{10} \text { ProSup }_{\mathrm{i}}+\varepsilon
\end{aligned}
$$

\begin{tabular}{llll}
\hline \multicolumn{1}{c}{ Type } & \multicolumn{1}{c}{ Variables } & Coefficient & t-statistics \\
\hline \multirow{3}{*}{\begin{tabular}{llll} 
Ownership Structure \\
\cline { 2 - 4 }
\end{tabular}} & State & $1.380^{*}$ & 0.011 \\
\cline { 2 - 4 } & Trade & $1.544^{* *}$ & 0.000 \\
\cline { 2 - 4 } & Owner & $2.729^{* *}$ & 0.000 \\
\cline { 2 - 4 } $\begin{array}{l}\text { Characteristics } \\
\text { of BOD }\end{array}$ & Dir & $0.123^{* *}$ & 0.001 \\
\cline { 2 - 4 } & Ind & -0.160 & 0.887 \\
\cline { 2 - 4 } & DirM & -0.225 & 0.132 \\
\cline { 2 - 4 } $\begin{array}{l}\text { Characteristics } \\
\text { of BOS }\end{array}$ & ProDir & 0.014 & 0.365 \\
\hline & Sup & $6.190 *$ & 0.023 \\
\hline & ProSup & $0.158^{* *}$ & 0.007 \\
\hline
\end{tabular}

Note: **** indicate, respectively, the significance level at the $1 \%$ and $5 \%$ level (2-tailed).

\section{SUMMARY AND CONCLUSION}

This study examines the association between corporate governance structures and accounting information disclosure quality using the data of Shenzhen Stock Exchange listed companies from 2011 to 2015. We find the following empirical evidence from our regression model analysis.

First, proportion of state-owned shares is positively associated with the accounting information disclosure quality. This indicates that the Chinese government fulfills its social responsibilities and operates its companies well. Second, the proportion of tradable shares is positively associated with the quality of accounting information disclosure. With the gradual improvement and development of market functions, Chinese shareholders participate effectively in corporate decision-making. Their participation helps to prevent management 
earnings manipulation and ultimately improve the quality of accounting information. Third, ownership concentration is positively associated with the quality of accounting information disclosure. This means that a certain degree of equity concentration is conducive to the improvement of the quality of accounting information disclosure in China. Forth, the size of board of directors is positively associated with the quality of the accounting information disclosure. The more members of the board, the more the experience and expertise of the board members in managing the company are. Larger size of board of directors improves the accounting information disclosure quality through more effective monitoring environment. Fifth, proportion of ownership of the board of directors is positively associated with the quality of accounting information disclosure. This proves that the implementation of equity incentive for board members is an effective way to improve the quality of accounting information disclosure in China. Sixth, the size of board of supervisors is positively associated with the quality of accounting information disclosure. If the board of supervisors and the board of directors are set in parallel, the board of supervisors is not subject to the leadership of the board of directors. Then, the board of supervisors can effectively monitor the duties of the board of directors and the management.

Nonetheless, we acknowledge that our findings may have following caveats. In the empirical analysis, we select the data of listed companies on the Shenzhen Stock Exchange for the five consecutive years from 2011 to 2015, not all the data of listed companies on the both Shanghai Stock Exchange and Shenzhen Stock Exchange. In the impact of corporate governance on the quality of accounting information disclosure, there may be differences between listed companies Shanghai Stock Exchange and Shenzhen Stock Exchange. For this reason may affect the accuracy of the analysis results. Next, there may be some factors that affect the accounting information disclosure quality. This study set ten hypotheses but does not cover all the factors on corporate governance structure.

Despite the limitation, this study may contribute to academics and disclosure-related practitioners by reporting various corporate governance which affects accounting disclosure quality in China. We also believe that our empirical evidence may shed light on the literature of Chinese corporate governance. 


\section{REFERENCES}

Alchian, Armen A., and Demsetz Harold. 1972. "Production, Information Costs, and Economic Organization." The American Economic Review 62(5): 777-795.

Art, Robert C., and Minkang Gu. 1995. "China Incorporated: The First Corporation Law of the People's Republic of China." Yale Journal of International Law 20: 273-308.

Beasley, Mark S. 1996. "An Empirical Analysis of the Relation between the Board of Director Composition and Financial Statement Fraud." The Accounting Review 71(4): 443-465.

Cai, Ning, and Liang Lizhen. 2003. "An Empirical Analysis of the Relation between Corporate Governance and Financial Statement Fraud." The Theory and Practice of Finance and Economics 24(6): 80-84. [In Chinese]

Chau, Gerald K., and Sidney J. Gray. 2002. "Ownership Structure and Corporate Voluntary Disclosure in Hong Kong and Singapore." The International Journal of Accounting 37(2): 247-265.

Chen, Han-wen, and Wen-xian Xia. 2003. "Independent Director Institution and Quality Control of Accounting Information: A Perspective of the Game Theory." Journal of Xiamen University 5: 94-100. [In Chinese]

Chtourou, Sonda M., Jean Bédard and Lucie Courteau. 2001. "Corporate Governance and Earnings Management." Working Paper, Laval University.

Clarke, Donald C. 2006. "The Independent Director in Chinese Corporate Governance." Delaware Journal of Corporate Law 31:125-228.

Du, Xingqiang, and Wen Riguang. 2007. "Corporate Governance and Quality of Accounting Information: An Empirical Research.” Journal of Finance and Economics 33(1): 122-133. [Printed in Chinese]

Jensen, Michael C., and William H. Meckling. 1976. "Theory of the Firm: Managerial Behavior, Agency Costs and Ownership Structure.” Journal of Financial Economics 3(4): 305-360.

Jung, Kooyul, and Soo Young Kwon. 2002. "Ownership Structure and Earnings Informativeness: Evidence from Korea." International Journal of Accounting 37(3): 301-325.

Klapper, Leora F., and Inessa Love. 2002. "Corporate Governance, Investor Protection, and Performance in Emerging Markets." Journal of Corporate Finance 10(5): 703-728.

Lau, A. K. L., \& J. Jin. 2013. "An overview of the independent director system in China." Company Lawyer 34(10): 321-326.

Liang, Jie, Wang Xuan, and Li Jinzhong. 2004 "An Empirical Research on Relationship between Modern Corporate Governance and Accounting Information Fraud." Nankai Business Review 7(6): 47-51. [Printed in 


\section{Chinese]}

Romano, R., 2004. "The Sarbanes-Oxley Act and the Making of Quack Corporate Governance." The Yale Law Journal 114(7): 1521-1611.

Shleifer, A., and R. Vishny. 1997. "A Survey of Corporate Governance.” Journal of Finance 52(3): 737-793.

Shleifer, A., and R. Vishny. 1986. "Large Shareholders and Corporate Control." Journal of Political Economy 94(3): 461-488.

Warfield, T., J. Wild, and K. Wild. 1995. "Positive Accounting Theory: A Ten Year Perspective." Accounting Review 65: 131-156.

Zhang, Ivy X. 2007. "Economic consequences of the Sarbanes-Oxley Act of 2002." Journal of Accounting and Economics 44(1-2): 74-115.

Zhang, Y., Wang Yan, Tang Yuanhu, and Cai Laixing. 2006. "Empirical Study of the Relationship between Earnings Management and Board of Directors of the Listed Company Features." Management review 18(3): 14-19. [In Chinese] 